J. Product. \& Dev., 17(1):25-48(2012)

\title{
AFFECTIVELY OF SOME BIOCIDES, JOJOBA OIL, DIMILIN AND DURSBAN AGAINST COTTON LEAFWORM, Spodoptera littoralis (Boisd.) UNDER LABORATORY CONDITIONS
}

\author{
W. M. H. Desuky ; Khattab ${ }^{2}$, M. M. El-Berry ${ }^{2}$, A. A.; Omar, R. E E $^{2}$ and \\ Y. A. Mettwaly ${ }^{1}$. \\ 1- Plant Protection Research Institute, Agricultural Research Center, Dokki, \\ Giza, Egypt. \\ 2 -Plant Protection Department, Faculty of Agriculture, Benha University, Egypt.
}

\section{ABSTRACT}

The present investigation was carried out under laboratory condition at Plant Protection Research Institute (Sharkia Branch) to evaluate, Protecto, Biovar, Biorinza, Jojoba oil, diflubenzuron and chlorpyrifos against Spodoptera littoralis.

Obtained results indicated that the mean duration period of the different larval instars of $S$. littoralis fed on castor bean oil leaves treated with different concentrations of Biovar, Biorinza, Protecto and jojoba oil. Cleared that all tested compounds caused markedly prolongation in the duration period of the larval instars compared to control. Generally, increasing the concentration caused increasing mortality percentage for the tested compounds. Also the tested compounds caused markedly prolongation in the duration period of the pupal stage. The lowest concentrations caused the highest percent deformation of pupae for the tested compounds. Biovar recorded highest reduction in percent of adult emergence. The higher concentration applied of the four compounds tested the higher percent of reduction in the eggs number per female. Chlorpyrifos was the most potent insecticide and diflubenzuron was the least toxic material to the cotton leafworm, the three applied concentrations of each tested compound decreased the total soluble protein in the $2^{\text {nd }}$ instar larvae of S. littoralis as compared to control at the inspected times. The tested compounds increased the activity of GOT and GPT enzymes in the $2^{\text {nd }}$ instar larvae as compared to control at different time intervals. And increased invertase activity after 2, 5 and 7 days of application.

Key words: Biocides, jojoba oil, dimilin \& dursban against cotton leafworm, Spodoptera littoralis (boisd). 


\section{INTRODUCTION}

Cotton is the most important natural textile fiber in the world and considered one of the major sources of the national income in Egypt due to its excellent and incomparable technological characters. However, cotton plants are exposed to be attacked by several pests allover growing stages that affected severely and negatively its productivity. The Egyptian cotton leaf worm, Spodoptera littoralis (Boisd.) is considered as the most important insect pest in Egypt. This destructive polyphagous pest causing substantial loss of different stages of cotton plantations could result in yield reduction up to 50\% (Russell et al., 1993).The control strategy was based mainly on uses of synthetic insecticides that are still one of the most powerful weapons that commonly used to control economically the significant epidemic infestation of this pest .The wide and misuse of insecticidal or pesticidal chemical compounds resulted in great damage caused to beneficial insects, including honeybees and beekeeping all over the world. (Toscano et al., 1974). Kanga et al., (2003) found that Metarhizium anisopliae was harmless to the honey bees. Andréev and Atanasova (2005) said that azadirachtin showed a low level of toxicity to predators. Czepak et al., (2005) cleared that diflubenzuron did not show negative effects on the complex of predators present in the cotton. Qiao et al., (2009) proved that Bacillus thuringiensis had no significant effects on live span of predators' adults. Ellis and Hayes (2009) found that B.t. is not harmful to honey bees.

Therefore, the present work aims to throw some light on the toxicity, biology and enzyme activities of $\boldsymbol{S}$. littoralis due to using some bio insecticides, botanical oil, I G R (Dimilin) and Dursban as control agents to the cotton leafworm.

\section{MATERIALS AND METHODS}

\section{Tested compounds:}

\subsection{Bioinsecticides:}

Protecto $^{\circledR}$ : Bacillus thuringiensis var. Kurstaki $32.000 \mathrm{IU} / \mathrm{mg}$ ). The recommended rate is $300 \mathrm{gm} / 100 \mathrm{~L}$ water.

Biovar $^{\circledR}$ : an etomopathegenic fungi, 32000 viable spore/mg) containing the fungus Beauveria bassiana applied at rate of $200 \mathrm{~g} / 100 \mathrm{~L}$ water.

Biorinza $^{\circledR}$ : Metarhizium anisopliae spore $10 \%$ W.P $\left(32 \times 10^{6}\right.$ spores $\left./ \mathrm{ml}\right)$ Rate $200 \mathrm{~g} / 100 \mathrm{~L}$ water.

Basic product of previous biocides Insect Pathogen Unite Plant Protection Research Institute, Agricultural Research Center Dokki, Giza ,Egypt. 
1.2. Dimilin ${ }^{\circledR}$ : (diflubenzuron): A commercial water dispersible powder (W.P.) containing 25\% diflubenzuron, Chemical name: 1-(4-chlorophenyl)-3(2.6-diflubenzoyl) urea was available for testing. The suspension at the rate of $0.5 \mathrm{~kg}$ formulation / Fadden.

1.3. Dursban ®: (Chlorpyrifos) $48 \%$ E.C. O,O-diethyl O-(3,5,6-trichloro-2pyridinyl) phosphorothioate. Used the rate of $1 \mathrm{~L} /$ feddan. Dow Agro science. 1.4. Jojoba oil: (plant oil is formulated as EC) produced by Egyptian Natural oil Co. used at the rate of $500 \mathrm{ml} / \mathrm{feddan}$.

\section{Rearing technique of the cotton leafworm Spodoptera littoralis (Boisd.) culture:} Laboratory strain of $\boldsymbol{S}$. littoralis was reared on castor bean leaves according to El- Defrawi, 1964 under laboratory conditions $25 \pm 2{ }^{\circ} \mathrm{C}$ and $65 \pm 5 \%$ R. H.

\subsection{Effect of bio-insecticide and plant oil on some biological aspects against Spodoptera littoralis:}

The leaf dipping technique was used to test the effect of Jojoba oil, Protecto, Biovar and Biorinza against the $2^{\text {nd }}$ instars larvae of S.littoralis. For larvicidal action, the $2^{\text {nd }}$ instar larvae of 1-day old were used, three successive dilutions were used for jojoba oil 5.00, 2.500, $1.250 \mathrm{ml} / \mathrm{L}, 6.00,3.00$ and 1.50 $\mathrm{gm} / \mathrm{L}$ for Protecto, 4.00,2.00and 1.00 gm/L for Biovar and 4.00,2.00and 1.00 $\mathrm{gm} / \mathrm{L}$ for Biorinza.

Water was used as solvent to obtain the tested concentrations, leaf disks $(3 \mathrm{~cm}$. diameter) of the fresh castor bean leaves punched with a cork borer, were dipped in the tested concentrations of Jojoba oil for 10 seconds, control disks were dipped in distilled water. The treated leaf disks were left to dry then offered to the larvae at the rate of one disk/one larva of S. littoralis and placed in a plastic cylinder tube of $3.4 \mathrm{~cm}$ diameter and $7.0 \mathrm{~cm}$ height and covered with a perforated plastic lid to permit good ventilation, filter paper was put upon the bottom to absorb any excess moisture. Three replicates of 10 larvae each were made per each concentration the larvae were allowed to feed on treated disks for $48 \mathrm{hr}$. then on untreated leaves. Data were recorded daily, this trial was carried out under laboratory conditions and recorded some biological criteria.

\subsection{Toxicity of the tested compounds against the second and the fourth instar larvae of Spodoptera littoralis: \\ The leaf dipping technique was applied to evaluate the insecticidal- activity} of organophosphoras chlorpyrifos against the $2^{\text {nd }}$ and $4^{\text {th }}$ instar larvae, successive dilutions were made for chlorpyrifos using distilled water to obtain the tested 
concentrations .i.e 480, 240, 120, 60, 30, 15, 7.5, 3.75, 1.9 and $0.94 \mathrm{mg} / \mathrm{L}$ and for insect growth regulators $625,312.5,156.3,78.1,39.0,19.5,9.8,4.9,2.44$ and $1.22 \mathrm{mg} / \mathrm{L}$. Mortality counts were made after 24 hour of exposure of chlorpyrifos and5days of diflubenzuron. Mortality data were corrected according to Abbott's formula (1925). Concentration mortality regression lines were statistically analyzed by Probit Analysis Finney (1971).

\section{Preparation of samples for biochemical assay:}

The preparation of samples involved the use of $2^{\text {nd }}$ and $4^{\text {th }}$ instar larvae after 2 and 5 days of treatment with IGR; as for Bioinsecticides and jojoba, the samples were collected from $2^{\text {nd }}$ instar larvae after 2,5 and 7days of application. As for chlorpyrifos the samples were collected from $4^{\text {th }}$ instar larvae after $1,3,5$ and 7 days of application. For each concentration applied, 1 gram Wight larvae were picked up and placed in clean jars, then starved for $4 \mathrm{hr}$., the starved larvae were homogenized in distilled water (1gram $/ 5 \mathrm{ml})$ using a taflon homogenizer surrounded with jacket of crunched ice for 3 minutes.

The homogenate was centrifuged at 3500 r.p.m for 10 minutes at $5 \mathrm{C}^{\circ}$. The supernatant was immediately assayed to determine total soluble protein and the activities of glutomic oxaloacetic transeaminase (GOT), glutomic pyruvic transeaminase (GPT), trehalase, amylase, and invertase enzymes.

Determination of total soluble protein: Colorimetric determination of total soluble protein in total homogenate larvae of $S$. littoralis was carried out as described by Gornall et al. (1949).

Transeaminase enzymes (GOT and GPT): The activities of glutamic oxaloacetic transeaminase (GOT) and glutamic pyruvic transeaminase enzymes were determined calorimetrically according to Reiteman and Frankel (1957).

Carbohydrate hydrolyzing enzymes (trehalase, invertase and amylase): Determination of trehalase, invertase and amylase enzymes activities in digesting trehalose, scrose and starch, respectively were determined according Ishaaya and Swiriski (1976).

\section{RESULTS AND DISCUSSIONS}

\section{Effect of tested bioinsecticides and Jojoba on some biological aspects against $S$. littoralis:}

\subsection{Larval Stage:}

It is obvious that, duration of the $2^{\text {nd }}$ larval instar of $\mathrm{S}$. littoralis fed on treated with Biovar, Biorinza, Protecto and Jojoba oil are shown in Table 1. 
Table 1. Biological aspects of the cotton leaf worm as affected by the Biovar applying, Biorinza, Protecto and Jojoba oil to the $2^{\text {nd }}$ instar larvae under laboratory condition.

\begin{tabular}{|c|c|c|c|c|c|c|c|c|c|}
\hline Compound & $\begin{array}{l}\text { Conc. } \\
\text { gm/L }\end{array}$ & $2^{\text {nd }}$ & $3^{\text {rd }}$ & $4^{\text {th }}$ & $5^{\text {th }}$ & $6^{\text {th }}$ & P.P & $\begin{array}{c}\text { Total } \\
\text { duration }\end{array}$ & $\begin{array}{c}\text { Mortality } \\
(\%)\end{array}$ \\
\hline \multirow[t]{3}{*}{ Biovar } & 4.00 & $2.44 \mathrm{a}$ & $2.8 \mathrm{a}$ & $3.72 \mathrm{a}$ & $2.9 \mathrm{a}$ & $3.83 \mathrm{a}$ & $1.83 \mathrm{a}$ & $17.5 \mathrm{a}$ & $80.0 \mathrm{a}$ \\
\hline & 2.00 & $2.37 \mathrm{a}$ & $2.94 \mathrm{a}$ & $3.58 \mathrm{a}$ & $2.9 \mathrm{a}$ & $3.8 \mathrm{a}$ & $1.7 \mathrm{a}$ & $17.3 \mathrm{a}$ & $66.7 \mathrm{~b}$ \\
\hline & 1.00 & $2.00 \mathrm{~b}$ & $2.63 \mathrm{a}$ & $3.81 \mathrm{a}$ & $2.7 \mathrm{a}$ & $3.7 \mathrm{a}$ & $1.67 \mathrm{a}$ & $16.53 \mathrm{~b}$ & $36.7 \mathrm{c}$ \\
\hline Control & - & $2.10 \mathrm{~b}$ & $2.13 b$ & $3.1 \mathrm{~b}$ & $2.13 \mathrm{~b}$ & $3.3 \mathrm{~b}$ & $1.62 \mathrm{a}$ & $14.4 \mathrm{c}$ & - \\
\hline F-test & - & *** & $* *$ & $* *$ & $* * *$ & $*$ & & $* * *$ & $* * *$ \\
\hline L.S.D & - & 0.1893 & 0.3950 & 0.332 & 0.2770 & 0.340 & N.S & 0.646 & 7.700 \\
\hline Mean & - & $2.26 \mathrm{~A}$ & $2.8 \mathrm{~A}$ & $3.7 \mathrm{C}$ & $2.8 \mathrm{~B}$ & $3.8 \mathrm{~B}$ & $1.73 \mathrm{AB}$ & 17.1 B & $61.1 \mathrm{~A}$ \\
\hline \multirow[t]{3}{*}{ Biorinza } & 4.00 & $2.3 \mathrm{a}$ & $2.76 \mathrm{a}$ & $3.67 \mathrm{a}$ & $2.6 \mathrm{a}$ & $3.67 \mathrm{a}$ & $1.7 \mathrm{a}$ & $16.7 \mathrm{a}$ & $66.7 \mathrm{a}$ \\
\hline & 2.00 & $2.13 \mathrm{a}$ & $2.5 \mathrm{~b}$ & $3.76 \mathrm{a}$ & $2.26 \mathrm{~b}$ & $3.63 \mathrm{a}$ & $1.75 \mathrm{a}$ & $15.73 b$ & $43.3 \mathrm{~b}$ \\
\hline & 1.00 & $2.1 \mathrm{a}$ & $2.3 \mathrm{bc}$ & $3.62 \mathrm{a}$ & $2.19 \mathrm{~b}$ & $3.4 \mathrm{ab}$ & $1.67 \mathrm{a}$ & $15.5 \mathrm{~b}$ & $33.3 \mathrm{c}$ \\
\hline Control & - & $2.1 \mathrm{a}$ & $2.13 \mathrm{c}$ & $3.1 \mathrm{~b}$ & $2.13 \mathrm{~b}$ & $3.3 \mathrm{~b}$ & $1.62 \mathrm{a}$ & $14.4 \mathrm{c}$ & - \\
\hline F-test & - & N.S & $* *$ & $* * *$ & $* *$ & N.S & N.S & $* * *$ & $* * *$ \\
\hline L.S.D & - & - & 0.258 & 0.226 & 0.1799 & - & - & 0.560 & 9.410 \\
\hline Mean & - & 2.17 & 2.49 B & $3.68 \mathrm{C}$ & $2.3 \mathrm{CD}$ & $3.56 \mathrm{C}$ & 1.7AB & $15.96 \mathrm{C}$ & $47.8 \mathrm{~B}$ \\
\hline \multirow[t]{3}{*}{ Protecto } & 6.00 & $2.28 \mathrm{ab}$ & $2.86 \mathrm{a}$ & $4.7 \mathrm{a}$ & $2.7 \mathrm{a}$ & $3.72 \mathrm{a}$ & $1.86 \mathrm{a}$ & $18.11 \mathrm{a}$ & $73.3 \mathrm{a}$ \\
\hline & 3.00 & $2.4 \mathrm{a}$ & $2.52 \mathrm{~b}$ & $3.9 \mathrm{~b}$ & $2.58 \mathrm{a}$ & $3.67 \mathrm{a}$ & $1.92 \mathrm{a}$ & $16.94 \mathrm{~b}$ & $60 \mathrm{~b}$ \\
\hline & 1.50 & $2.13 b$ & $2.9 \mathrm{a}$ & $3.58 \mathrm{c}$ & $2.46 \mathrm{ab}$ & $3.7 \mathrm{a}$ & $1.67 \mathrm{ab}$ & $16.54 \mathrm{~b}$ & $36.7 \mathrm{c}$ \\
\hline Control & & $2.1 \mathrm{~b}$ & $2.13 \mathrm{c}$ & $3.1 \mathrm{~d}$ & $2.13 b$ & $3.31 \mathrm{~b}$ & $1.62 \mathrm{~b}$ & $14.4 \mathrm{c}$ & - \\
\hline F-test & & $*$ & $* * *$ & ***** & $*$ & $*$ & N.S & $* * *$ & $* * *$ \\
\hline L.S.D & & 0.218 & 0.217 & 0.18 & 0.348 & 0.298 & - & 0.929 & 7.685 \\
\hline Mean & & $2.26 \mathrm{~A}$ & $2.76 \mathrm{~A}$ & $4 B$ & $2.56 \mathrm{C}$ & $3.76 \mathrm{C}$ & $1.83 \mathrm{~A}$ & 17.17B & $56.7 \mathrm{~A}$ \\
\hline \multirow[t]{3}{*}{ Jojoba } & 5.00 & $2.35 \mathrm{a}$ & $2.96 \mathrm{a}$ & $4.6 \mathrm{a}$ & $3.65 \mathrm{ab}$ & $4.6 \mathrm{a}$ & $1.9 \mathrm{a}$ & $19.45 \mathrm{a}$ & $70.00 \mathrm{a}$ \\
\hline & 2.50 & $2.38 \mathrm{a}$ & $2.9 \mathrm{a}$ & $4.35 \mathrm{a}$ & $3.9 \mathrm{a}$ & $4.5 \mathrm{a}$ & $1.78 \mathrm{ab}$ & $20.18 \mathrm{a}$ & $53.3 \mathrm{~b}$ \\
\hline & 1.25 & $2.13 \mathrm{~b}$ & $2.8 \mathrm{a}$ & $4.19 b$ & $3.3 \mathrm{~b}$ & $3.92 \mathrm{~b}$ & $1.78 \mathrm{ab}$ & $18.2 \mathrm{~b}$ & $33.3 \mathrm{c}$ \\
\hline Control & - & $2.1 \mathrm{~b}$ & $2.13 b$ & $3.1 \mathrm{c}$ & $2.13 \mathrm{c}$ & $3.3 \mathrm{c}$ & $1.62 \mathrm{ab}$ & $14.4 \mathrm{c}$ & - \\
\hline F-test & - & $* *$ & $* * *$ & $* * *$ & $* * *$ & $* * *$ & N.S & $* * *$ & $* * *$ \\
\hline L.S.D & - & 0.157 & 0.1720 & 0.2193 & 0.631 & $0.144 b$ & - & $0.79 \mathrm{a}$ & 7.68 \\
\hline Mean & - & $0.28 \mathrm{~A}$ & $2.88 \mathrm{~A}$ & $4.5 \mathrm{~A}$ & $3.63 \mathrm{~A}$ & $4.15 \mathrm{~A}$ & $1.82 \mathrm{~A}$ & $19.3 \mathrm{~A}$ & $52.7 \mathrm{~A}$ \\
\hline Control & & $2.1 \mathrm{~B}$ & $2.13 \mathrm{C}$ & $3.1 \mathrm{D}$ & $2.13 \mathrm{D}$ & $3.3 \mathrm{D}$ & $1.62 \mathrm{~B}$ & $14.4 \mathrm{D}$ & - \\
\hline F-test & & N.S & $* * *$ & $* * *$ & $* * *$ & $* * *$ & * & $* * *$ & $* * *$ \\
\hline L.S.D & & - & 0.181 & 0.265 & 0.235 & 0.183 & 0.13 & 0.254 & 14.6 \\
\hline
\end{tabular}

ranged between $2.00-2.44,2.1-2.3,2.16-2.4$ and 2.13- 2.38, respectively compared to 2.1 days for control larvae. Results showed that the highest mean of larval duration recorded 2.28 days with jojoba, while lowest one was 2.17 days with Biorinza.

Data presented in Table (1) clear that the duration period for the $3^{\text {rd }}$ larval instars ranged from 2.63- 2.94, 2.3- 2.76, 2.52- 2.9 and 2.8- 2.96 days for larvae fed on castor bean oil leaves treated with Biovar, Biorinza, Protecto and jojoba oil, respectively. Jojoba induced the highest prolongation, whereas Biorinza 
caused the lasted effect the concentration seamed to be less effective in general 2.49 days.

The period of stay of the $4^{\text {th }}$ larval instars ranged between $3.58-3.8$, 3.623.76, 3.58- 4.7 and 4.19- 4.6 days for larvae with Biovar, Biorinza, Protecto and jojoba oil Table 1. It is obvious that jojoba oil induced the highest prolongation in the duration period of the $4^{\text {th }}$ instars. The lowest concentration of Protecto caused the lowest prolongation in the duration period of this instars (3.58 days). However, control recorded (3.10) days only. The time spent of the $5^{\text {th }}$ larval instars of $S$. littoralis larvae with Biovar Biorinza, Protecto and jojoba oil ranged between 2.70- 2.9, 2.19- 2.6, 2.46- 2.7 and 3.30- 3.9, respectively compared to 2.13 days for control larvae. Jojoba oil induced the highest prolongation, While Biorinza recorded lowest prolongation (i.e.2.19 days) at the concentration of $1.0 \mathrm{gm} / \mathrm{l}$.

The $6^{\text {th }}$ larval instars was recorded with Biovar, Biorinza, Protecto and Jojoba oil, duration ranged between 3.7- 3.83, 3.40- 3.67, 3.67- 3.72 and 3.924.6 day compared to 3.31 days recorded for control larvae. Generally, the highest concentration caused the highest prolongation whereas the lowest concentration induced the lowest prolongation especially in case of Jojoba oil 4.6 days.

As shown in Table 1, the duration period of prepupa ranged between (1.62 - 1.92) days for treated larvae with the tested compound whereas it recorded 1.62 days for control larvae. obtained results indicated that the mean duration period of the different larval instars of $S$. littoralis with different concentrations of Biovar, Biorinza, Protecto and jojoba oil recorded (16.53- 17.5, 15.5- 16.70, 16.54- 18.11 and 18.20- 20.18 days, respectively. The respective figure far the control larvae recorded (14.40) days. It is clear that all tested compounds caused markedly prolongation in the duration period of the larval instars compared to control, such results are in agreement with Dimtrey et al., (1998) who proved that neem extract caused prolongation in the larval duration of S.littoralis. They same trend recorded by Mead (2006) who treated $2^{\text {nd }}$ and $4^{\text {th }}$ instars with sub lethal concentrations of Tracer and triflumuron lead to prolongation in the larval duration also Abbassy et al., (2007) proved the antifeedant activity in Jojoba, Simmondsia chinensis_is a result of simmondsin (glycosides) contents in the extract. Mortality percentage of S. littoralis, in case of Biovar, Biorinza, Protecto and Jojoba oil ranged between 36.7- 80, 33.3- 66.7,36.7- 73.3 and 33.3- $70 \%$ for the tested compounds, respectively. Generally, increased the concentration caused increased mortality for the tested compounds. Similar results obtained by Ghatak et al., (2005) found that Effect of Neem plus on the third instars larvae of S. littoralis $0.5,1$ and $2 \%$ the range $40-60 \%$ at 96 hours after treatment. 
Data presented in Table (1) indicate that the cumulative percent of larval bioinsecticides, obtained results agreed with Abd El-Aziz (2000) and Dutton et al., (2003) proved that Dipel 2x B.t. significantly affected S. littoralis larvae as the development time required by larvae that fed on B.t. sprayed plant.

It is obvious that Biovar proved to be the most potent larvicidal compound, while Biorinza is the least toxic effect against lepidopteron larvae was also reported by several authors such as Bekheit and El-Abbas (2002) stated that Metarhizium anisopliae are active against the $2^{\text {nd }}$ and $4^{\text {th }}$ instars larvae of $S$. littoralis.

In general. the mortality of $S$. littoralis larvae increased with increasing dosage of the pathogen. Malinowski (2006) found that $B$. $t$. are active against some species of Lepidoptera and show a short durability of action.

\subsection{Pupal stage: \\ Pupation:}

Data presented in Table (2) indicate that the percent of larval pupation of Spodoptera littoralis with Biovar, Biorinza, Protecto and Jojoba oil ranged between $2063.4,33.30-66.70,26.763 .3$ and 3066.4 for the tested compound, respectively. Generally, the higher of concentrations caused the higher the reduction percentage of pupation. Decreasing the pupation percentages as a result of treating $S$. littoralis with plant extracts and bioinsecticides reported by several authors such as Badr et al., (2000) who mentioned that the plant seed oil extracts decreased the percent of pupation of S. littoralis with bioinsecticides recorded by Attalla et al., (2001) who mentioned that B.t. products recorded a negative relationship observed between concentrations and pupation percentages. Farrag (2000) proved that Beauveria bassiana treatment, to $S$. littoralis lowered the percentages of pupation according to increasing in concentrations.

Obtained results indicated that the mean time spent of the pupal stage of treated S.littoralis larvae with different concentrations of Biovar, Biorinza, Protecto and Jojoba oil recorded (9.65 - 11, 9.42 - 10.44, $10.00-10.5$ and 10.56 - 11.3) days, respectively. It is clear that the tested compounds caused markedly prolongation in the duration period of the pupa stage. Generally, the higher of the concentrations induce the higher prolongation of pupal stage

for the tested compounds. Prolongation in pupal duration as a result of treating S. littoralis with such insecticides was also reported by Marie et al., (2009) who found that Jojoba and sesame oil extracts pronounced prolonged pupal duration of S. littoralis. 
Table 2: Biological aspects of the cotton leafworm pupae as affected by the applying Biovar, Biorinza, Protecto and Jojoba oil to the $2^{\text {nd }}$ instar larvae under laboratory conditions.

\begin{tabular}{|c|c|c|c|c|c|c|c|}
\hline Compound & $\begin{array}{l}\text { Conc. } \\
\text { g/L }\end{array}$ & $\begin{array}{c}\text { Pupation } \\
(\%)\end{array}$ & $\begin{array}{c}\text { Duration } \\
\text { (days) }\end{array}$ & \begin{tabular}{|c|}
$\begin{array}{c}\text { Pupal weight } \\
\text { (gm) }\end{array}$ \\
\end{tabular} & $\begin{array}{c}\text { +or- } \\
(\%)\end{array}$ & Malformation & $\begin{array}{c}\text { Mortality } \\
(\%)\end{array}$ \\
\hline \multirow[t]{3}{*}{ Biovar } & 4.00 & $20 d$ & $11.00 \mathrm{a}$ & $0.2667 \mathrm{c}$ & -21.5 & - & $50 \mathrm{a}$ \\
\hline & 2.00 & $33.3 \mathrm{c}$ & $10.4 \mathrm{~b}$ & $0.2700 \mathrm{bc}$ & -19.7 & $14.3 \mathrm{a}$ & $19.4 \mathrm{~b}$ \\
\hline & 1.00 & $63.36 \mathrm{~b}$ & $9.65 \mathrm{c}$ & $0.2880 \mathrm{~b}$ & -15.1 & - & $12.26 \mathrm{bc}$ \\
\hline Control & - & $96.7 \mathrm{a}$ & $9.31 \mathrm{~d}$ & $0.3396 \mathrm{a}$ & - & - & - \\
\hline$\overline{\text { F-test }}$ & - & $* * *$ & $* * *$ & $* * *$ & - & $* * *$ & $* *$ \\
\hline L.S.D & - & 9.414 & 0.244 & 0.017 & - & 1.58 & 19.18 \\
\hline Mean & - & 38.9 B & $10.36 \mathrm{~B}$ & $0.2750 \mathrm{C}$ & - & 4.76AB & 27.2A \\
\hline \multirow[t]{3}{*}{ Biorinza } & 4.00 & $33.3 \mathrm{c}$ & $10.44 \mathrm{a}$ & $0.2890 \mathrm{~b}$ & -14.9 & $8.3 \mathrm{a}$ & $22.2 \mathrm{a}$ \\
\hline & 2.00 & $56.7 \mathrm{~b}$ & $9.7 \mathrm{~b}$ & $0.2880 \mathrm{~b}$ & -14.92 & $11.13 \mathrm{a}$ & $13.3 \mathrm{a}$ \\
\hline & 1.00 & $66.7 \mathrm{~b}$ & $9.42 \mathrm{bc}$ & $0.3090 \mathrm{~b}$ & -9.00 & $15.1 \mathrm{a}$ & $15.57 \mathrm{a}$ \\
\hline Control & - & $96.7 \mathrm{a}$ & $9.31 \mathrm{c}$ & $0.3396 \mathrm{a}$ & - & - & - \\
\hline F-test & - & $* * * *$ & $* * *$ & $* *$ & - & $\mathbf{N . S}$ & $\mathbf{N . S}$ \\
\hline L.S.D & - & 10.87 & 0.280 & 0.025 & - & - & - \\
\hline Mean & - & $52.2 \mathrm{~B}$ & $9.85 \mathrm{C}$ & 0.2950 B & - & 11.52 A & $13.73 \mathrm{AB}$ \\
\hline \multirow[t]{3}{*}{ Protecto } & 6.00 & $26.7 \mathrm{~d}$ & $10.5 \mathrm{a}$ & $0.2650 \mathrm{c}$ & -21.95 & - & $38.9 \mathrm{a}$ \\
\hline & 3.00 & $40.0 \mathrm{c}$ & $10.4 \mathrm{a}$ & $0.2827 \mathrm{bc}$ & -16.750 & $16.7 \mathrm{a}$ & $8.3 \mathrm{~b}$ \\
\hline & 1.50 & $63.3 \mathrm{~b}$ & $10.00 \mathrm{ba}$ & $0.2963 \mathrm{~b}$ & -12.750 & $21.43 \mathrm{a}$ & - \\
\hline Control & & $96.7 \mathrm{a}$ & $9.31 \mathrm{c}$ & $0.3396 \mathrm{a}$ & - & - & - \\
\hline \multirow{3}{*}{$\begin{array}{l}\text { F-test } \\
\text { L.S.D } \\
\text { Mean }\end{array}$} & & $* * *$ & $* *$ & $* * *$ & - & $*$ & $* *$ \\
\hline & & 9.444 & 0.5290 & 0.0258 & - & 16.70 & 16.34 \\
\hline & & $43.3 \mathrm{~B}$ & 10.33 B & 0.2913 BC & & 12.7A & 15.7A \\
\hline \multirow[t]{3}{*}{ Jojoba } & 5.00 & $30 \mathrm{~d}$ & $11.30 \mathrm{a}$ & $0.2400 \mathrm{~b}$ & -29.32 & - & $44.43 \mathrm{a}$ \\
\hline & 2.50 & $46.7 \mathrm{c}$ & $11.00 \mathrm{a}$ & $0.2573 \mathrm{c}$ & -24.34 & $13.3 \mathrm{a}$ & $25 \mathrm{ab}$ \\
\hline & 1.25 & $66.7 \mathrm{~b}$ & $10.56 \mathrm{~b}$ & $0.2799 \mathrm{~b}$ & -17.8 & $19.87 \mathrm{a}$ & $12.23 \mathrm{bc}$ \\
\hline Control & - & $96.7 \mathrm{a}$ & $9.31 \mathrm{c}$ & $0.3396 \mathrm{a}$ & - & - & - \\
\hline F-test & - & $* * *$ & $* * *$ & $* * *$ & - & $*$ & $* *$ \\
\hline L.S.D & - & 9.414 & 0.348 & 0.0920 & - & 13.04 & 20.7 \\
\hline Mean & - & 47.8 B & $10.96 \mathrm{~A}$ & $0.2590 \mathrm{D}$ & - & $11.06 \mathrm{~A}$ & $27.2 \mathrm{~A}$ \\
\hline Control & & $96.7 \mathrm{~A}$ & $9.31 \mathrm{D}$ & $0.3396 \mathrm{~A}$ & - & - & - \\
\hline F-test & & $* * *$ & $* * *$ & $* * *$ & - & $*$ & $* * *$ \\
\hline L.S.D & & 14.75 & 0.340 & 0.0140 & - & 8.87 & 15.44 \\
\hline
\end{tabular}

Obtained results indicated that the weight of pupae resulted from treated S.littoralis larvae with the three applied concentrations of the tested compounds recorded (0.2667gm - 0.2883, 0.2880- 0.3090, 0.2650 - 0.2963 and $0.2400-$ 0.2799 gm for Biovar, Biorinza, Protecto and Jojoba oil, respectively. Jojoba oil recorded highly decrease of weight pupa in high concentrations while Biorinza recorded the lowest decrease of pupal weight as compared with untreated pupae. Decreasing pupae weight as a result of treating $S$. littoralis larvae with plant 
extracts and Bioinsecticides in harmony with results obtained by Bekheit and EAbbas (2002) who did not record any significant difference in pupal weight among larvae treated with both Beauveria bassiana and Metarhizium anisopliae, but significant differences were observed between treated and untreated larvae. Data presented in Table (2) indicate that the presented deformation of pupa produced in different concentrations of Biovar, Biorinza, Protecto and Jojoba oil ranged between $(0-14.3,8.3-15.1,0-21.43$ and $0-19.87) \%$ for the tested compound, respectively. Generally, the lowest the concentration caused the highest percent deformation of pupa for the tested compound. Similarly, Dimitry et al., (1998) reported that pupa deformation was found when they tested the extracts of 16 wild plants against Spodoptera littoralis larvae. In addition, Farrag (2000) and Attala et al., (2001) reported the same conclusion when treated S. littoralis with bioinsecticides.

Date presented in Table (2) indicate that Biovar treatment caused (12.26 $50 \%$ ) pupae mortality with the highest and least concentration, respectively. In case of Biorinza it recorded $22.2 \%$ pupae mortality with the recommend rate. In case of Protecto the percent of mortality ranged between $8.3 \%$ and $38.9 \%$. In case of Jojoba oil the percent mortality ranged between $12.23 \%$ and $44.43 \%$ pupal mortality with the recommend rate. El-Aw (2003) reported that Dipel 2x significantly reduced pupae survival after treating $S$. littoralis larvae with B.t. products.

Generally, it could be concluded that Biovar induced the severest latent effect on pupal stage of $S$. littoralis larvae fed on castor bean oil leaves treated with the three concentration of the Biovar. For instance, it caused the least percent of pupation, the highest elongation in the duration period of pupa stage and the highest percent mortality. Mean while, Biorinza proved to be the least compound in this respect the higher percent pupation of larvae as well as least elongation of the duration period of pupa stage. Data of present work partially disagreed with those of Marei et al., (2009) Jojoba and Sesame oil extracts caused pronounced prolongation in both larval and pupa duration.

\subsection{Adult stage (Moth):}

Data presented in Table (3) clear that percentage of adult emergence recorded 50- 73.8, 72.22- 80.15, 61.13- 78.52 and 55.57- 69.18 for Biovar, Biorinza, Protecto and Jojoba oil, respectively. Biovar recorded highest reduction in percent of adult emergence. Decreasing emergence percentages of adults resulting from treated $S$. littoralis larvae with the extracts and bioinsecticides Attala (2001). 
Table 3: Biological aspects of the cotton leaf worm adult as affected by the applying Biovar, Biorinza, Protecto and Jojoba oil to the $2^{\text {nd }}$ instar larvae under laboratory conditions.

\begin{tabular}{|c|c|c|c|c|c|c|}
\hline Compound & $\begin{array}{c}\text { Conc. } \\
\text { g/L }\end{array}$ & Emergence & $\begin{array}{c}\text { Longevity } \\
\text { of male } \\
\text { (days) }\end{array}$ & $\begin{array}{c}\text { Longevity of } \\
\text { female } \\
\text { (days) }\end{array}$ & $\begin{array}{c}\text { No. of egg } \\
\text { per } \\
\text { female }\end{array}$ & $\begin{array}{c}\text { Hatchability } \\
(\mathbf{\%})\end{array}$ \\
\hline Biovar & 4.00 & $50.00 \mathrm{c}$ & $7.00 \mathrm{c}$ & $6.00 \mathrm{~b}$ & $1350 \mathrm{~d}$ & $17.04 \mathrm{~d}$ \\
& 2.00 & $69.44 \mathrm{~b}$ & $7.70 \mathrm{c}$ & $6.70 \mathrm{ab}$ & $1850 \mathrm{c}$ & $31.42 \mathrm{c}$ \\
Control & 1.00 & $73.8 \mathrm{~b}$ & $8.61 \mathrm{~b}$ & $7.37 \mathrm{a}$ & $1965 \mathrm{~b}$ & $38.80 \mathrm{~b}$ \\
\hline F-test & - & $100 \mathrm{a}$ & $9.67 \mathrm{a}$ & $7.36 \mathrm{a}$ & $3124.8 \mathrm{a}$ & $98.16 \mathrm{a}$ \\
L.S.D & - & $* * *$ & $* * *$ & N.S & $* * *$ & $* * *$ \\
Mean & - & 9.267 & 0.8650 & - & 154.123 & 9.267 \\
\hline Biorinza & 4.00 & $72.22 \mathrm{~b}$ & $7.50 \mathrm{~b}$ & $6.50 \mathrm{a}$ & $1725 \mathrm{~d}$ & $24.00 \mathrm{~d}$ \\
& 2.00 & $77.80 \mathrm{~b}$ & $7.76 \mathrm{~b}$ & $6.7 \mathrm{a}$ & $2020 \mathrm{c}$ & $39.95 \mathrm{c}$ \\
Control & 1.00 & $80.15 \mathrm{~b}$ & $7.11 \mathrm{~b}$ & $6.7 \mathrm{a}$ & $2407 \mathrm{~b}$ & $55.86 \mathrm{~b}$ \\
\hline F-test & - & $100 \mathrm{a}$ & $9.67 \mathrm{a}$ & $7.36 \mathrm{a}$ & $3124.8 \mathrm{a}$ & $98.46 \mathrm{a}$ \\
\hline L.S.D & - & $* *$ & $* * *$ & $\mathrm{N.S}$ & $* * *$ & $* * *$ \\
Mean & - & 15.45 & 0.6405 & - & 143.40 & 2.680 \\
\hline Protecto & 6.00 & $61.13 \mathrm{c}$ & $7.33 \mathrm{c}$ & $6.50 \mathrm{~b}$ & $1425 \mathrm{~d}$ & $19.65 \mathrm{~b}$ \\
& 3.00 & $75.00 \mathrm{~b}$ & $7.83 \mathrm{c}$ & $7.00 \mathrm{ab}$ & $1833.3 \mathrm{c}$ & $24.00 \mathrm{c}$ \\
& 1.50 & $78.57 \mathrm{~b}$ & $8.66 \mathrm{~b}$ & $7.44 \mathrm{a}$ & $2171.7 \mathrm{~b}$ & $43.06 \mathrm{~b}$ \\
Control & - & $100 \mathrm{a}$ & $9.67 \mathrm{a}$ & $7.36 \mathrm{a}$ & $3124.8 \mathrm{a}$ & $98.46 \mathrm{a}$ \\
\hline F-test & - & $* *$ & $* * *$ & $*$ & $* * *$ & $* * *$ \\
L.S.D & - & 13.31 & 0.8230 & 0.8830 & 67.188 & 2.37 \\
Mean & & $\mathbf{7 1 . 5 7 ~ B C}$ & $\mathbf{7 . 4 4 ~ B}$ & $\mathbf{7 . 0 4} \mathbf{A B}$ & $\mathbf{1 8 5 8 . 1 2} \mathbf{~ B}$ & $\mathbf{3 0 . 0 0 ~ C}$ \\
\hline Jojoba & 5.00 & $55.57 \mathrm{~b}$ & $6.70 \mathrm{c}$ & $6.00 \mathrm{c}$ & $873.0 \mathrm{~d}$ & $24.45 \mathrm{~d}$ \\
& 2.50 & $65.00 \mathrm{~b}$ & $7.67 \mathrm{~b}$ & $6.70 \mathrm{bc}$ & $1700 \mathrm{c}$ & $38.11 \mathrm{c}$ \\
Control & 1.25 & $69.18 \mathrm{~b}$ & $8.22 \mathrm{~b}$ & $7.16 \mathrm{ab}$ & $2008.3 \mathrm{~b}$ & $52.76 \mathrm{~b}$ \\
\hline F-test & - & $100.00 \mathrm{a}$ & $9.67 \mathrm{a}$ & $7.36 \mathrm{a}$ & $3124.8 \mathrm{a}$ & $98.46 \mathrm{a}$ \\
\hline L.S.D & - & $* * *$ & $* * *$ & $*$ & $* * *$ & $* * *$ \\
Mean & - & 20.044 & 0.8550 & 0.83 & 169.96 & 3.8820 \\
\hline Control & & $100 \mathrm{~A}$ & $9.67 \mathrm{~A}$ & $7.36 \mathrm{~A}$ & $3124.8 \mathrm{~A}$ & $98.5 \mathrm{~A}$ \\
\hline F-test & & $* * *$ & $* * *$ & $*$ & $* * *$ & $* * *$ \\
\hline L.S.D & & 12.423 & 0.6330 & 0.5740 & 328.38 & 10.774 \\
\hline
\end{tabular}

The longevity of male moth resulted from $S$. littoralis larvae fed on castor been oil leaves dipped in different concentration recorded (7- 8.61, 7.5- 8.11, 7.33- 8.66 and 6.7- 8.22) days for Biovar, Biorinza, Protecto and Jojoba oil, respectively. Control male moth lived 9.66 days.

Generally, the higher concentration applied of the four tested compounds resulted in the higher percent reduction in the longevity of male moth. 
Obtained results clear that the longevity of female moth recorded $(6,6.7$ and 7.37) days for Biovar treated insects at 4, 2 and $1 \mathrm{gm} / \mathrm{L}$, respectively. As for the Biorinza tested concentration (4, 2 and $1 \mathrm{gm} / \mathrm{L}$ ). As for the Protecto tested concentration 6,3 and $1.5 \mathrm{gm} / \mathrm{L}$ the longevity of female moths recorded 6.5, 7 and 7.44 days respectively. As for Jojoba oil tested concentration 5, 2.5 and $1.25 \mathrm{gm} / \mathrm{L}$ the longevity of female moths recorded 6.00, 6.70 and 7.16 days for the three descending concentration. It is clear that least concentration in case B.t. $1.5 \mathrm{gm} / 1$ recorded the highest elongation recorded $7.4 \mathrm{a}$ days. While the higher concentration of Biovar recorded the least effect as far higher concentration of Jojoba oil recorded (6.00) this statement is accord with that of El-Meniawi et al., (1999) who stated that the harmful effect of Neem seed extract is more pronounced on male than female of $S$. littoralis.

The total number of eggs laid per female moth resulted from larvae fed on castor bean oil leaves treated with different concentrations of Biovar, Biorinza, Protecto and Jojoba oil recorded 1350, 1850 and 1965 eggs at (4,2and $1 \mathrm{gm} / \mathrm{L})$ of Biovar; 1725, 2020 and 2407 eggs at (4, 2 and 1) $\mathrm{gm} / \mathrm{L}$ of Biorinza; 1425, 1833.3 and 2171.7 eggs at $(6,3$ and $1.5 \mathrm{gm} / \mathrm{L})$ of Protecto; 873,1700 and 2008.20 at $(5,2.5$ and $1.25 \mathrm{gm} / \mathrm{L})$ of Jojoba oil, respectively. Control female moths laid on average (3124.8a) eggs /female. Generally, the higher concentration applied of the four compounds tested the higher percent of reduction in the eggs number /female (Table 3). Such results are in the same trend of those obtained by El-Meniawi et al., (1999) and Ghoneim (2007) who recorded a diver sable effects of number of eggs laid by females resulted from larvae treated with plant extracts.

Data obtained indicated that percent of hatchability of S. littoralis eggs laid by moths resulted from larvae fed on castor bean oil leaves treated with different concentrations of the tested compounds ranged from 17.04- 38.86; 24- 55.8; 19.65- 43.06 and 24.45- 52.76 for Biovar, Biorinza, Protecto and Jojoba oil, respectively. However, percent of hatchability of control eggs recorded (98.54) it is clear that the highest concentrations of Biovar, Biorinza, Protecto and Jojoba oil caused the highest the percent of reduction in the hatchability. The same trend was also reported by Dimetry et al., (1998) recorded significant adverse effects on the fecundity of resulting adults from $S$. littoralis larvae exposed to Neem extract. As for Badr et al., (2000) found that plants extract were reduced of percentage of hatchability for egg- mass. El-Aw (2003) said that egg hatchability reduced by Dipel 2x treatment to S. littoralis. 


\section{Toxicity of Dursban and Dimilin against second and fourth instars of Spodoptera littoralis larvae: \\ Effect on the $2^{\text {nd }}$ instar larvae:}

Data given in Table (4) show that the order of efficiency of the tested insecticides against the $2^{\text {nd }}$ instar larvae was the same at both $\mathrm{LC}_{50}$ and $\mathrm{LC}_{90}$. At both mentioned levels, Dursban was the most potent insecticide and Dimilin was the least toxic material to the cotton leafworm. The corresponding or $\mathrm{LC}_{50}$ values were: 0.162 and $9.546 \mathrm{ppm}$, respectively, while these values were 4.319 and $178.064 \mathrm{ppm}$ at $\mathrm{LC}_{90}$, respectively. At the $\mathrm{LC}_{50}$ level, the toxicity of diflubenzuron reached $1.697 \%$ as compared with $100 \%$ by chlorpyrifos on the second instar larvae.

The $\mathrm{LC}_{50}$ values in $4^{\text {th }}$ were $4.895,24.715$ ppm for Dursban and Dimilin, respectively, At $\mathrm{LC}_{90}$ switch in position occur the chlorpyrifos was the more effective than diflubenzuron. The corresponding values were 29.966 and $602.605 \mathrm{ppm}$, respectively. The toxicity index of a standard insecticide used is always taken as $3.309 \%$ there for chlorpyrifos, chlorpyrifos against the $2^{\text {nd }}$ instar larvae was consider standard chemicals in calculating the toxicity index. The toxicity of diflubenzuron was $0.655 \%$ compared with chlorpyrifos (i.e. $100 \%$ toxicity). The present conclusion was in harmony with. Aschwinder - Kaur et al., (2007) proved that chlorpyrifos was the most potent toxicant against $S$. littoralis larvae according to LC50 values.

Table 4: Susceptibility of the $2^{\text {nd }}$ and $4^{\text {th }}$ instar larvae of the laboratory strain of cotton leaf worm Spodoptera littoralis (Boisd.) against tested insecticides.

\begin{tabular}{|l|c|c|c|}
\hline Tested compounds & $\begin{array}{c}\text { LC } \\
\text { ppm }\end{array}$ & \multicolumn{1}{|c|}{$\begin{array}{c}\text { LC } \\
\text { ppm }\end{array}$} & $\begin{array}{c}\text { Toxicity } \\
\text { index }\end{array}$ \\
\hline \multicolumn{5}{|c|}{$\mathbf{2}^{\text {nd }}$} \\
\hline Chlorpyrifos & 0.162 & 4.319 & 100 \\
\hline Diflubenzuron & 9.546 & 178.064 & 1.697 \\
\hline \multicolumn{5}{|c|}{$\mathbf{4}^{\text {th }}$} \\
\hline Chlorpyrifos & 4.895 & 29.966 & 3.309 \\
\hline Diflubenzuron & 24.715 & 602.605 & 0.655 \\
\hline
\end{tabular}


Index compared to Dursban on $2^{\text {nd }}$ instar

\section{Biochemical changes.}

\section{Bioinsecticides and Jojoba oil:}

As shown in Table (5) the three applied concentrations of each tested compound decreased the total soluble protein in the $2^{\text {nd }}$ instar larvae of $S$. littoralis as compared to control at the inspected times 2, 5, 7 days, except least concentration of Biorinza after two days of treatment. The highest decrease in the total soluble protein recorded $42.2 \%$ and $45.8 \%$ after five days of treatment with Protecto at $6 \mathrm{gm} / \mathrm{L}$ and Jojoba oil at $5 \mathrm{gm} / \mathrm{L}$. while the no effect was recorded after two days of Biorinza treatment at the least concentration. The same trend was obtained by El-Sheikh et al., (1990) who found that treating the $4^{\text {th }}$ instar larvae of $S$. littoralis with plant extract cased reduction in total protein. The activity of GOT enzyme in the $2^{\text {nd }}$ instar larvae of $S$. littoralis was increased at different time intervals as affected by all the concentration of the Bioinsecticides and Jojoba oil. The highest increase in the activity of GOT was $150 \%$ in control that recorded after two days of treatment with the highest concentration of Jojoba oil, whereas the least was $75 \%$ was the control for Jojoba oil at least concentration after seven days and Biorinza at least concentration after seven days recorded $90 \%$ considered the control as $100 \%$. Other concentrations caused intermediate increase in GOT activity and ranged between $100 \%$ - 138.7 as the control (Table 5).

Data in Table (5) reveal that all concentrations applied of the tested compounds caused increase in GPT activity in the supernatant of the homogenate larvae at all examined times. This increase ranged between as 106.7 $-278.20 \%$ as the control for Biorinza at $1 \mathrm{gm} / \mathrm{L}$ after two days and Protecto at the highest concentration after seven days, respectively. It is obvious that the highest enzyme activity was detected at seven days after treatment. In addition, the higher the concentration of Protecto and Jojoba oil resulted in the higher the enzyme activity. Generally, the tested compound increased the activity of GOT and GPT enzymes in the $2^{\text {nd }}$ instar larvae as compared to control at different time intervals. These results are in agreement with those of El-Sheakh et al., (1990) who recorded an Increase in GOT and GPT activity of $S$. littoralis $\left(4^{\text {th }}\right.$ instar larvae) after treatment with $\mathrm{LC}_{50}$ of plant extranet. Data given in Table (5) show the changes in trehalase activity in the $2^{\text {nd }}$ instars larvae of $S$. littoralis. It is clear that the tested compounds caused considerably increase in the activity of the enzyme. The highest activity was recorded with Biovar at highest concentration 
Table5: Total soluble protein content and transeaminase enzymes \% in the supernatant of homogenated $S$. littoralis the $2^{\text {nd }}$ instar larvae affected by Bioinsecticides and plant extract treatment.

\begin{tabular}{|c|c|c|c|c|c|c|c|c|c|c|}
\hline \multirow{3}{*}{ Compound } & \multirow{3}{*}{$\begin{array}{l}\text { Conc. } \\
\text { gm/L }\end{array}$} & \multirow{2}{*}{\multicolumn{3}{|c|}{$\begin{array}{c}\text { Total soluble protein } \\
\text { after }\end{array}$}} & \multicolumn{6}{|c|}{ Transeminase enzymes } \\
\hline & & & & & \multicolumn{3}{|c|}{ GOT\% after } & \multicolumn{3}{|c|}{ GPT \% after } \\
\hline & & 2days & 5days & 7days & 2days & 5days & 7days & 2days & 5days & 7days \\
\hline \multirow{3}{*}{ Jojoba } & 5.0 & 90 & 45.8 & 64 & 150 & \begin{tabular}{|l|}
95.2 \\
\end{tabular} & \begin{tabular}{|c|}
106.9 \\
\end{tabular} & \begin{tabular}{|l|l}
195.8 \\
\end{tabular} & 222.5 & 256.2 \\
\hline & 2.5 & 95 & 58.8 & 68.8 & 115.33 & 93.6 & 80 & 166.25 & 200.7 & 241.66 \\
\hline & 1.25 & 95 & 70 & 75 & 106.7 & 95.2 & 75 & 159.67 & 186.5 & 241.6 \\
\hline \multirow{3}{*}{ Protecto } & 6.0 & 83.7 & 42.2 & 64 & 126.5 & 100 & 105 & 178.25 & 200.4 & 278.2 \\
\hline & 3.0 & 90 & 47.7 & 64.3 & 110 & 110 & 107 & 169.5 & 194.7 & 241.7 \\
\hline & 1.5 & 98 & 46.52 & 75 & 107.5 & 100 & 105 & 148 & 182 & 233 \\
\hline \multirow{3}{*}{ Biovar } & 4.0 & 80.54 & 51.97 & 70.42 & $\mid 138.7$ & 120 & 133 & 149.75 & 140 & 207 \\
\hline & 2.0 & 85 & 53.11 & 74 & 126.5 & 132 & 130 & 150 & 159.2 & 221.7 \\
\hline & 1.0 & 98 & 60.64 & 83.5 & 108.8 & 134.2 & 133 & 160.5 & 159.2 & 247 \\
\hline \multirow{3}{*}{ Biorinza } & 4.0 & 90 & 60 & 75.8 & 109.50 & $\mid 121.7$ & 100 & 123.3 & 198 & 246 \\
\hline & 2.0 & 95 & 68.6 & 82.16 & $\mid 115.7$ & 123.6 & 100 & 120.8 & 149 & 220 \\
\hline & 1.0 & 106 & 76.5 & 83.3 & 100.5 & 125 & 90 & 106.7 & 132.1 & 200 \\
\hline
\end{tabular}

after seven days of treatment being as $366.75 \%$ as compared with control while the least effect was recorded after two days of Protecto treatment at the least concentration. Similar results were obtained by Abo-El Ghar et al., (1996) who found that a considerable increase in the activities of trehalase after feeding the $6^{\text {th }}$ instars of Agrotis ipsilon larvae on most selected bioinsecticides.

The tested compound caused increase in invertase activity after 2,5 and 7 days of application. However, the highest enzyme activity was recorded with Biovar as it reached as 160, 140 and $250.7 \%$ compared with control. Mean while. The least enzyme activity was noticed in Protecto treated larvae (Table 6).Generally, the saved effect was noticed at 7 days after application for the compound tested in addition, the increase in invertase activity is directly proportional with the concentrations. As show in Table (6) the entire tested compound increased the activity of amylase enzyme in the $2^{\text {nd }}$ instar larvae. Biovar recorded the highest increase in amylase actively after 7 days of treatment that recorded as 255,241 and $185 \%$ as that of the control at 4,2 
Table 6. Trehalase, invertase and amylase enzymes \% in the supernatant of the homogenated S.littoralis $2^{\text {nd }}$ larvae affected by Bioinsecticides and plant extract treatment.

\begin{tabular}{|c|c|c|c|c|c|c|c|c|c|c|}
\hline \multirow{2}{*}{ Compound } & \multirow{2}{*}{$\begin{array}{l}\text { Conc. } \\
\text { gm/L }\end{array}$} & \multicolumn{3}{|c|}{$\begin{array}{c}\text { Trehalase\% } \\
\text { after }\end{array}$} & \multicolumn{3}{|c|}{$\begin{array}{c}\text { Invertase \% } \\
\text { after }\end{array}$} & \multicolumn{3}{|c|}{$\begin{array}{c}\text { Amylase \% } \\
\text { after }\end{array}$} \\
\hline & & 2days & 5days & 7days & 2days & 5days & 7days & 2days & 5days & 7days \\
\hline \multirow{3}{*}{ Jojoba } & 5 & $245 \%$ & 197 & 365 & 166.5 & 146.5 & 224 & 165.4 & 163.4 & 227 \\
\hline & 2.5 & 218 & 200 & 330 & 160.8 & 146.1 & 208.7 & 150.4 & 148.4 & 205 \\
\hline & 1.25 & 200 & 189 & 314 & 156.8 & 125.2 & 193.04 & 130 & 145.27 & 200 \\
\hline \multirow{3}{*}{ Protecto } & 6 & 194.6 & 140.34 & 340.75 & 163.8 & 170.17 & 188.3 & 165.4 & 157.317 & 252 \\
\hline & 3 & 178.31 & 128.93 & 366.5 & 156.7 & 139.48 & 170.95 & 138.4 & 138.93 & 244 \\
\hline & 1.5 & 140.4 & 119.16 & 300.5 & 130.8 & 126.36 & 166.95 & 128 & 129.14 & 230 \\
\hline \multirow{3}{*}{ Biovar } & 4 & 247.7 & 189.2 & 366.75 & 160 & 140 & 250.7 & 165 & 135.27 & 255 \\
\hline & 2 & 236.9 & 177.3 & 316.5 & 143 & 138.7 & 213.26 & 199.6 & 148.5 & 241 \\
\hline & 1 & 200.9 & 168.5 & 308 & 137.2 & 123.1 & 183.4 & 112 & 128.5 & 185 \\
\hline \multirow{3}{*}{ Biorinza } & 4 & 244.8 & 193.18 & 350 & 177 & 158.5 & 219.9 & 152 & 147.64 & 227 \\
\hline & 2 & 225 & 180 & 300 & 150 & 136.45 & 196.5 & 134.7 & 147.6 & 227 \\
\hline & 1 & 209.34 & 145 & 300 & 136.8 & 121.73 & 181.2 & 120 & 114 & 205 \\
\hline
\end{tabular}

and $1 \mathrm{gm} / \mathrm{L}$, respectively Jojoba oil caused the highest recording as 163.4, 150.45 and $130 \%$ as that control at $5,2.5$ and $1.25 \mathrm{gm} / \mathrm{L}$, respectively. Biorinza recorded the lost increase in the amylase activity. In this connection, Abo-El-Ghar et al., (1996) recorded significant decrease in invertase enzyme activity in the $6^{\text {th }}$ instars larvae of Agrotis ipsilon due to feeding larvae on the ethanol extracts of Melia azedarach and Vinca rosa, all the tested Bioinsecticides caused noticeable fluctuations in the total soluble protein, transeminase enzymes and carbohydrate hydrolyzing enzymes Jojoba, Protecto and Biovar were the most Bioinsecticides, while Biorinza was the least effective one.

\section{Insect growth regulator and organophosphorous:}

Data in Tables (7 and 8) show the level in the total soluble protein detected in the $2^{\text {nd }}$ and $4^{\text {th }}$ instar larvae treated with $\mathrm{LC}_{50}$ of the tested IGR and chlorpyrifos. It is obvious that all the tested compound in both the $2^{\text {nd }}$ and $4^{\text {th }} S$. littoralis larvae decreased the total soluble protein as compared to control at the inspected times 1, 3, 5, 7, days except Dimilin after one day. The highest decrease in the total soluble protein recorded 51.6 and $58 \%$ after 1 day of treatment with Dursban at the $2^{\text {nd }}$ and $4^{\text {th }}$ instars larvae, respectively. 
DESUKY et al. 
In this connection, Mostafa (1993) showed significant decrease in the level of total soluble protein as affected by IGR. Both fluenoxuron and teflubenzuron were more effective on the $6^{\text {th }}$ instar larvae than $4^{\text {th }}$ instar ones of S. littoralis. Data in Tables ( $7 \& 8$ ) show GOT levels in the $2^{\text {nd }}$ in star larvae were $25.00 \%$ and $100 \%$ after 1 day post treatment with chlorpyrifos and diflubenzuron, respectively compared with $100 \%$ in control. The respective values with the $4^{\text {th }}$ instars larvae were 50.00 and $90 \%$, compared with 100 in control. After 3 days of treatment, GOT values were 50 and $125 \%$ in the $2^{\text {nd }}$ in star larvae whereas these figures were $40.5 \%$ and $121 \%$ of chlorpyrifos and diflubenzuron, respectively, in case of the $4^{\text {th }}$ in star larvae. Data demonstrate that chlorpyrifos decrease the levels of GOT but diflubenzuron in the $2^{\text {nd }}$ in star increase the activity of GOT compared with control treatment.

GPT levels in (Tables $7 \& 8$ ) were $56.5 \%$ and $175 \%$ in case of the $2^{\text {nd }}$ instar larvae whereas values were $45 \%$ and $190 \%$ in case of the $4^{\text {th }}$ instar larvae after 1 day of treatments with chlorpyrifos and diflubenzuron, compared to $100 \%$ in control treatment, respectively. After 3 days post treatment, GPT levels in case of the $2^{\text {nd }}$ in star larvae were $81.5 \%$ and $150 \%$ for the two tested compounds, respectively. Incase of the $4^{\text {th }}$ instar larvae, values were $85 \%$ and $150.33 \%$ after the treatment with tested chemicals ,respectively compared to $100 \%$ for the two tested instars in control treatments, respectively after 7 days post treatment, most treated individuals were dead. Significant and highly significant differences between the treatments were noticed. Khedr et al., 2005 studied the biochemical effects of live insect growth regulators namely: Cascade, Atabron, Consult, Match and Mimic, castor bean leaves treated with 9 successive concentrations of each IGR. The obtained results indicated that Atabron proved to be the most potent IGRs, whereas Mimic was the least to toxic the $2^{\text {nd }}$ and the $4^{\text {th }}$ instar larvae. The $4^{\text {th }}$ instar larvae proved to be more sensitive to all the tested IGR, then the $2^{\text {nd }}$ one at all tested concentration the tasted IGR decreased the activity at the 2 day post treatment in the $2^{\text {nd }}$ instar larvae. The anvils were true at 5 days post treatment. In case of the $4^{\text {th }}$ instar, the tested IGR increased the activity of the two enzymes after the 2 and 5 days of treatment.

Data given in Tables ( $9 \& 10)$ summarize the changes of trehalase in both the $2^{\text {nd }}$ and $4^{\text {th }}$ instar larvae of $S$. littoralis. The $2^{\text {nd }}$ instar larvae showed increase in trehalase activity 1 day after treating with Dursban and Dimilin. The highest activity was recorded at Dursban $175 \%$, whereas the least value $125 \%$ was 
DESUKY et al. 
recorded with Dimilin. After 3 days of treatment the $2^{\text {nd }}$ instar larvae treated with the different of tested compound increased in trehalase. The highest value $195 \%$ was recorded at Dimilin. It is clear that the $4^{\text {th }}$ instar larvae showed that increase in the trehalase activity after 1 day in both Dimilin and Dursban. Dimilin recorded the highest values $175 \%$ while Dursban recorded $150 \%$. Data in Tables ( $9 \& 10$ ) clear that at 1 day after application of the $2^{\text {nd }}$ instar larvae the tested compound affected on the enzyme of invertase, Dursban induced greatly the enzyme activity. Meanwhile, Dimilin seemed to be ineffective. After five days of treatment, Dursban induced noticeable increase in invertase activity. Dimilin coursed slight increase. After 7 days of treatment, Dimilin caused increase in the activity invertase enzyme. In case of the $4^{\text {th }}$ instar larvae, after one day of treatment, Dursban recorded the highest increase of activity $131 \%$, while Dimilin recorded at $\mathrm{LC}_{50} 100 \%$ no effect. After 3days of treatment, Dursban recorded $136 \%$ while Dimilin recorded $110 \%$. After five days of treatment Dursban increased the enzyme activity $119.7 \%$, while Dimilin recorded $115 \%$. After seven days of treatment, Dimilin increased the enzyme activity and recorded $140 \%$. Data in Tables (9 \&10) show the changes in activity of amylase enzyme after 1 day of treatment the $2^{\text {nd }}$ instars larvae with the tested compounds. It is clear that Dursban caused decrease in the enzyme activity $(75 \%)$, while Dimilin induced slight or no effect on the amylase activity. Similarly, the amylase enzyme after 3,5 and 7 days of treatment showed slight or no response to the Dursban and Dimilin application.

Regarding, the effect of the tested compounds on the $4^{\text {th }}$ instar larvae on activity of amylase after 1 day of treatment, it is clear that Dursban was decreased in the enzyme activity. Dimilin induced the enzyme activity. After 3 days of treatment Dursban and Dimilin recorded 100\% and 87\%, respectively. After 5 and 7 days of treatment showed decreased amylase activity with Dursban and Dimilin.

In general, the activity of carbohydrate hydrolyzing enzyme; trehalase, invertase and amylase revealed the following; the $4^{\text {th }}$ instar larvae proved to more sensitive than the $2^{\text {nd }}$ instar larvae in case of Dimilin. Amylase activity seemed to be more tolerant to the IGR, application whereas trehalase was the most sensitive. Dursban more potent than Dimilin. Al- Elimi and Eid (1998) found an increase in carbohydrate hydrolyzing enzyme activity after treating larvae of S. littoralis with different concentration of the IGR diflubenzuron and buprofezin. Khedr et al., (2005) studied the biochemical effect of five insect growth regulators IGR, namely; Cascade, Atabron, Consult, Match and Mimic against the $2^{\text {nd }}$ and $4^{\text {th }}$ instar larvae of $S$. littoralis under laboratory condition. 
Atabron proved to be the most potent insect growth regulator, whereas Mimic was least toxic one among the treated IGR, against both the $2^{\text {nd }}$ and $4^{\text {th }}$ instar larvae. The $4^{\text {th }}$ instar larvae proved to be more sensitive to all the tested IGR, then the $2^{\text {nd }}$ on at all tested concentrations. The tested IGR decreased the activity of GOT while it increased GPT activity at 2 days post treatment the $2^{\text {nd }}$ instar larvae. Incase of the $4^{\text {th }}$ instar, the tested IGR, increased at activity of the two enzymes after 2 and 5 days of treatment.

Conclusively, it could be concluded that biocides and jojoba oil will be effective in case of controlling new hatched, young instars and low populations of S. littoralis. Otherwise, IGRs and OP compounds will be more efficient in case of different instars infestation and high populations.

\section{REFERENCES}

Abbassy, M. A.; Abdelgaleil, S. A. M.; Belal, A. S. H. and Rasoul, M. A. A. A. (2007): Insecticidal, antifeedant and antifungal activities of two glucosides isolated from the seeds of Simmondsia chinensis. Industrial Crops and products, 26(3):345-350.

Abbott, W.S. (1925): A method of computing the effectiveness of an insecticide. Journal of Econ. Ent., 18 (2): 265-267.

Abd-El-Aziz, H. S. (2000): Phsiopathological studies on bacterial infection of cotton leafworm, Spodoptera littoralis. M.Sc. Thesis, Faculty of Agriculture, Ain Shams Univeristy, Egypt, 144 p.

Abo-El-Ghar, G. E. S.; Khalil, M. E. and Eid, T. M. (1996): Some biochemical effects of plants extracts on the black cutworm, Agrotis ipsilon (Hufnagel) (Lep: Noctuidae). J. Appl. Ent., 120 (8):477-482.

Al- Elimi, M. H. and Eid, A. M. H. (1998): Effect of some Insect growth regulators on the activity of nonspecific esterase, phosphorus and carbohydrate hydrolyzing enzymes in S. littoralis. Egypt. J. Appl. Science, 13 (10): 286-294.

Andreev, R. and Atanasova, D. (2005). Toxicity of insecticides to predatory ladybirds (Coleoptera: Coccinellidae) under laboratory conditions. Bulgarian Society Entomological Society, 11(18): 7- 15.

Ashwinder-Kour; Kang, B. K. and Balwinder Singh. (2007): Toxicity of different insecticides against Spodotera litura (Fabricius) in Punjab, India. Pesticide Research Journal, 19 (1): 47-50. 
Atalla, F. A.; Elzogby, A. A. and Eweis, M. A. (2001): Susceptibility of the three lepidopterous pests, Seasamia cretica (led), Spodoptera littoralis (Boisd.) and Agrotis ipsilon (Hufn.) to the bacterial biocide Agerin. Egyptian Journal of Biological pest. Control, 11 (1/2): 45-49.

Badr, N. A.; Mohamed, S. A. and El-Haleem, S. M. A. (2000): Effect of seed oil extracts on the different developmental stages of the Egyptian cotton leaf worm, Spodoptera littoralis. Egyptian Journal of Biological Pest Control, 10 (1/2): 39-50.

Bekheit, H. K. M.; El-Abbas, F. A. (2002): Pathogenicity of entomogeneous fungi (hyphomycetes) to larvae of the cotton leaf worm, Spodoptera littoralis. Arab-universities Journal of Agricultural Sciences, 10 (1): 405-416.

Czepak, C; Fernandes, P. M.; Da-Takatsuka, F. S. and Broges, J. D. (2005): Selectivity of insecticides on the complex of natural enemies on cotton crop. Universidade Federal de Goia, Escola de Agronomie Engenharia de Alimentos, Goiania, Brazil, Pesquisa, Agropecuariatropical, 35(1/2) 23-127.

Dimetry, N. Z. El-Gengaihi, S. and Mohamed, S. M. (1998): The effect of lipoidal matter of neem fruits and leaves on Spodoptera littoralis development and reproduction. Journal of Insect Science and its Application, 18 (4):325-331.

Dutton, A.; Klein, H.; Romeis, J. and Bigler, F. (2003): Prey mediated effects of Bacillus thuringiensis spray on predator Chrysoperia carnea in maize. Biological Control, 26 (2): 209-215.

El-Aw, M.A. (2003): Bioassays and sub lethal effects aspects of the cotton leaf worm, Spodoptera littoralis (Boisd.). Alexandria Journal of Agric. Research, 48 (3):73-82.

El-Defrawi, M., A. A. Toppozada, A. E. Salama and El-Khishen, S. A. (1964): Toxicological studies on the Egyptian cotton leafworm, Prodenia litra F. II Reversion of Toxaphane resistant in Egyptian cotton leafworm. Journal Econ. Entomology, 57: 595 - 597.

Ellis, A. M. and Hayes, G. W. (2009): Assessing the efficacy of a product containing Bacillus thuringiensis applied to honey bee foundation as a control for Galleria mellonella. Journal of Entomological Science, 44 (2): 158- 163.

El-Meniawi, F. A.; Hashem, M.; EL-Mesieri, S. M. and Rawash, I. A. (1999): Physiological effect of neem seed extracts on the reproductive activities of the cotton leafworm, S. littoralis. Alex. J. Agric. Research, 44 (1):79- 96. 
El-Sheakh, A. A.; Mohamed, Z. A.; Ahmed, N. M. and Allam, S. M. (1990): Biological and biochemical changes occurring in Spodoptera littoralis larvae treated with osbic, cyanox and soybean phytoalexin. Egyptian Applied Science, 5 (4): 292-200.

Farrag, R.M. (2000): Interaction of caffeine with some insecticides on the cotton leaf worm. Egyptian Journal of Agricultural Research, 78 (5): 1959-1964.

Finney, D. J. (1971). Probit. Analysis, A Statistical Treatment Of The Sigmoid Response Curve. $7^{\text {th }}$ Ed., Cambridge Univ. Press, Cambridge, England.

Ghatak, S. S.; Reza, M.W. and Mamoni-Bhattacharjya (2005): Bio-efficacy of indigenous plant products on tobacco caterpillar, Spodoptera littoralis (F.) (Noctuidae: Lepidoptera. Environment and Ecology; 23s (Special 4): 751-753.

Ghoneim, K. S.; Amer, M. S; Bream, A. S; Al-Dali, A. G. and Hamadah, K. S. (2007): Effectiveness of Margosan-O and Jojoba on some reproductive aspects of the house fly, Musca domestica Diptera: Muscidae. International Journal of Agriculture and Biology, 9 (2): 338-341.

Gornall, A. G.; Bardawil, C. D. and David, M. M. (1949): Determination of serum protein by means of biuret reaction, J. Biochemistry, 177: 751-766.

Ishaaya, I. and Swiriski, E. (1976): Trehalase, invertase and amylase activities in the black scale, Saissetia oleae and their relation to host captivity. $J$. Ins. Physiology, 16: 1025-1029.

Kanga, L. H. B.; Jones, W. A. and James, R. R. (2003): Field trials using the fungal pathogen, Metarhizium anisopliae (Deuteromycetes: Hyphomycetes) to control the ecto parasitic mite, Varroa destructor (Acari: Varroidae) in honey bee, Apis mellifera (Hymenoptera: Apidae) colonies.). Journal of Economic Entomology, 96 (4): 1091-1099.

Khedr, M. M. A.; Desuky, W. M. H.; El-Shakaa, S. M. A. and YousifKhalil, S. I. (2005): Toxicological and Biochemical studies on effect of some Insect growth regulators on S. littoralis larvae. Egyptian Journal of Agriculture Research, 83 (2): 539-561.

Malinowski, H. (2006): Biodiversity and forest protection against harmful insects. Progress in Plant Protection, 46 (1): 319-325.

Marei, S. S.; Amr, E. M. and Salem, N. Y. (2009): Effect of some plant oils on biological, physiological and biochemical aspects of Spodoptera littoralis (Boisd.) Pakistan, Research Journal of Agriculture and Biological Sciences, 5(1): 103- 107. 
Mead, Hala, M. I. (2006) Studies on biochemical and biological activates of some larvicidal agents on cotton leafworm, S. littoralis (Boisd.) (Lepidoptera: Noctuidae). Ph. D. Thesis, Faculty of Agriculture, Suez Canal University, Egypt, 220p.

Mostafa, A. M. (1993): The efficiency of certain plant extracts as method of controlling meditation fruit fly, Ceratitis capitatai and their effect on its biotic potential. Ph. D. Thesis, Faculty of Agriculture, Menofia Shebin El Kom University, Egypt.

Qiao L. Q.; Qu, L. J.; Yang, Z. Q.; Zhang, Y. A.; Guan, L. and Yan, R. (2009): Effects of different pesticides on Chouioia cunea Yang, an important enemy of Hyphantria cunea Drury. China Forest Research, Beijing, 22(4): 559- 562.

Reiteman, S. and Frankel, F. (1957): Colourmetric method for aspertate and alanine transaminase. Amer. J. Clin. Pathology, 28-56.

Roy, H. E.; Cottrell, T. E; Evans, E. W.; Kavallietatos, N. G.; Lucas, E; Mackauet, M. and Michud, J. P. (2008). Forgotten natural enemies: Interactions between coccinellidae and insect-parasitic fungi. European Journal of Entomology, 105 (3): 391- 398.

Russell, D. A.; Radwan, S. M.; Irving, N. S.; Jones, K. A. and Downham, M. C. (1993): Experimental assessment of the impact of defoliation by Spodoptera littoralis on the growth and yield of Giza 75 cotton. Crop Protection, 12 (4): 303-309.

Sun, P.Y. (1950): Toxicity index- An improved method of comparing the relative toxicity of insecticides. J. Econ. Ent., 43: 45-53.

Toscano, N. C.; Mueller, A. J. Sevacheran, R. K. Sharna, R. K.; Nillus, T. and Reynolds, H. T. (1974): Insecticidal applications based on hexlure trap catches versus automatic schedule treatments for pink bollworm moth control. Journal of Econ. Ent., 67 (4):522-524. 


\title{
فعالية بعض المبيدات الحيوية و زيت الجوجوبا و الديميلين والدورسبان على دودة ورق القطن تحث الظروف المعملية
}

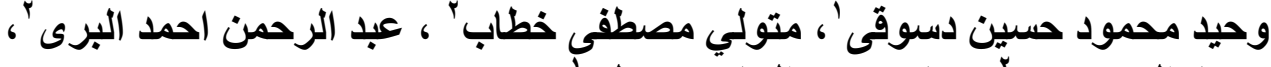

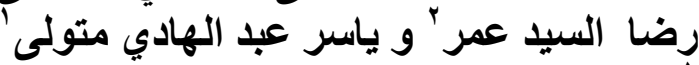

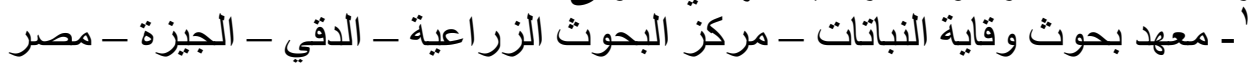

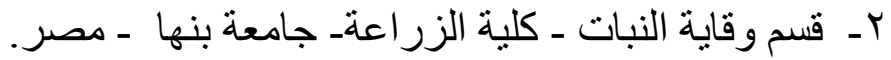

أجريت هذه الدر اسة بمعامل معهد بحوث وقاية النبات فرع الثرقية خلال الفترة

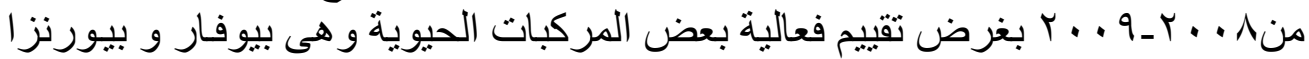

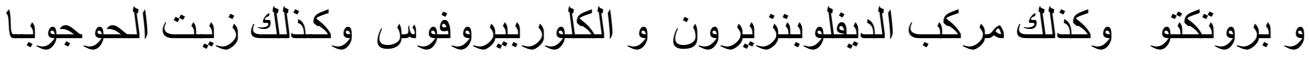

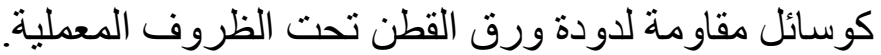

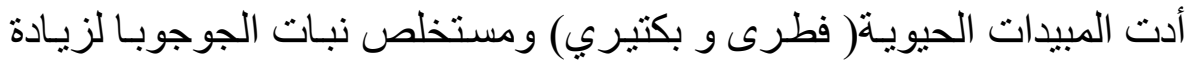

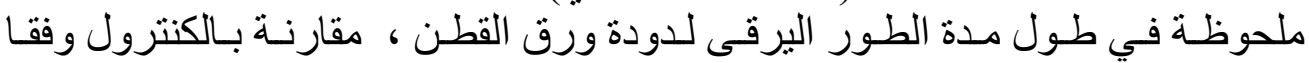

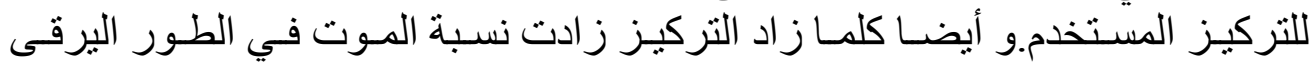

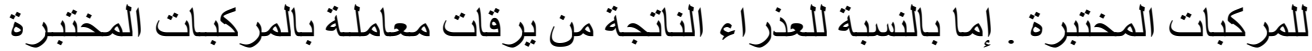

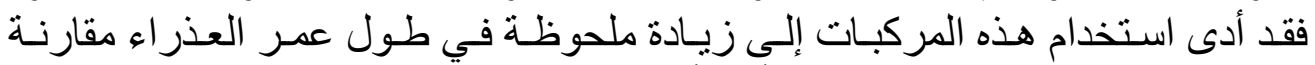

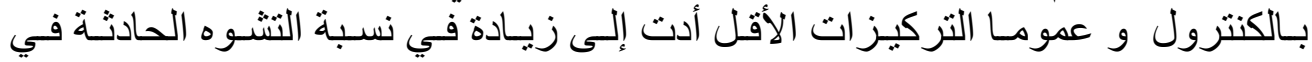

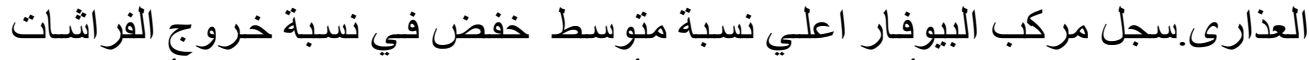

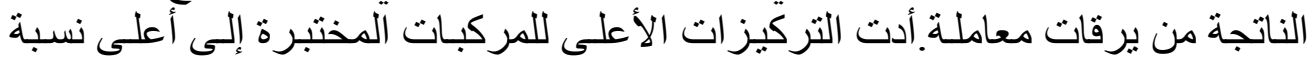

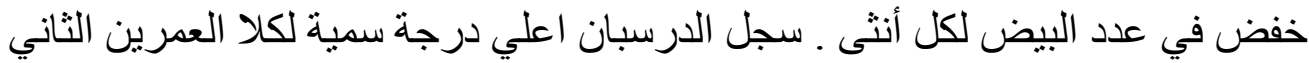

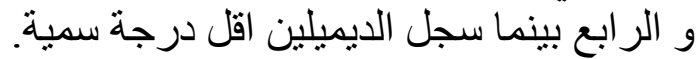

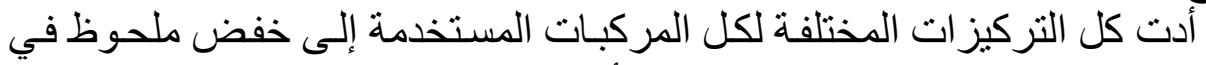

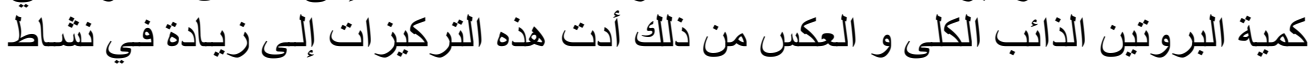

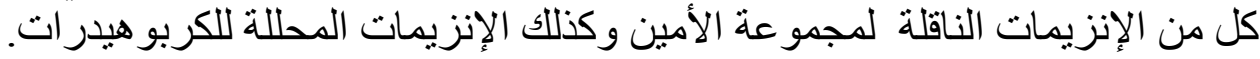

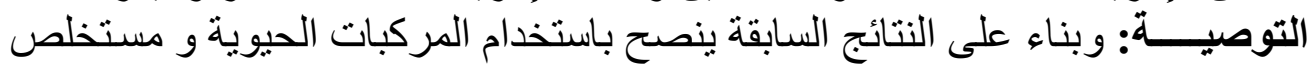

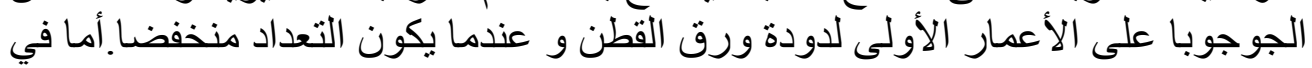

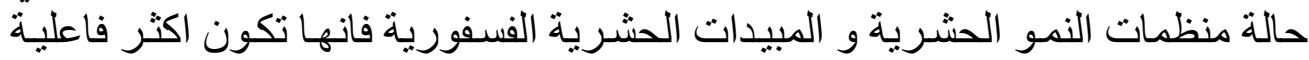
عند ارتفاع التعداد و تواجد أعمار يرقيه مختلفة من دودة ورق المبرات القطن. 